\title{
ORIGINAL
}

\section{Simultaneous Determination of Alteration of a Variety of Macrophage Functions Related to Natural Immunity Following Treatment with a DP Receptor Agonist}

\author{
Kiyoshi Daito*, Yasutaka Azuma**, Michiharu Daito* and Kiyoshi Ohura** \\ ${ }^{*}$ Department of Pediatric Dentistry, Osaka Dental University \\ ** Department of Pharmacology, Osaka Dental University \\ *,**8-1 Kuzuhahanazono-cho, Hirakata 573-1121, Japan
}

[Received on April 25, 2002 ; Accepted on August 19, 2002)

Key words: $\mathrm{PGD}_{2} /$ macrophage $/ \mathrm{TNF}-\alpha /$ natural immunity

\begin{abstract}
Prostaglandin $\mathrm{D}_{2}\left(\mathrm{PGD}_{2}\right)$ acts via the adenyl cyclase-coupled receptor for $\mathrm{PGD}_{2}$ (DP receptor). Here we present evidence that $\mathrm{BW} 245 \mathrm{C}$, a DP receptor agonist, modulates macrophage functions related to natural immunity. BW245C inhibited macrophage chemotaxis at concentrations of 0.1 to $10 \mu \mathrm{M}$ and phagocytosis of Escherichia coli by macrophages at a concentration of $10 \mu \mathrm{M}$. In addition, BW245C inhibited the production of superoxide anions by PMA-stimulated macrophages at concentrations of 0.1 to $10 \mu \mathrm{M}$ and nitrite production by LPS-stimulated macrophages at a concentration of $10 \mu \mathrm{M}$. In contrast, BW245C potentiated the production of TNF- $\alpha$, a pro-inflammatory cytokine, by LPS-stimulated macrophages at concentrations of 1 to $10 \mu \mathrm{M}$. These results suggest that $\mathrm{PGD}_{2}$ may modulate macrophage functions related to natural immunity via the DP receptor.
\end{abstract}

\footnotetext{
抄録：プロスタグランジン $\mathrm{D}_{2}\left(\mathrm{PGD}_{2}\right)$ は，その受容体である $\mathrm{DP}$ 受容体を介して作用することが知られている。 今回われわれは, DP 受容体アゴニストである BW245C が, 自然免疫系において重要な機能的役割を演じるマク ロファージの機能に対して影響を与えることを見いだした。BW245C はマクロファージ遊走能に対しては, 0.1 か

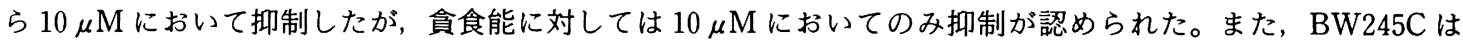
PMA 刺激条件下でのスーパーオキサイド産生能を 0.1 から $10 \mu \mathrm{M}$ において抑制したのに対して, LPS 刺激条件 下での $\mathrm{NO}$ 産生能は $10 \mu \mathrm{M}$ においてのみ抑制がみられた。さらに, 炎症性サイトカインである TNF- $\alpha$ に対して は, LPS 刺激条件下において BW245C は 1 および $10 \mu \mathrm{M}$ において増強効果を示した。以上の結果より, $\mathrm{PGD}_{2}$ は その受容体を介してマクロファージ機能に影響を与える可能性が示唆される。
}

\section{Introduction}

Periodontitis is a bacterially induced chronic inflammatory disease that is the major cause for tooth loss in the adult population. The current disease paradigm for the manifestation of periodontitis involves both a bacterial and a natural host defense system. The inflammatory response is a fundamental component of the natural immunity system. Macro- phages are commonly the first cells of the immune system to encounter invaders such as bacteria. The macrophage response to infection is initiated by adhesion to vascular endothelial cells, and progresses to directed cell migration into the extravascular tissue. Macrophages result in phagocytosis and intracellular killing of the invading microorganisms by the generation of bactericidal reactive oxygen species derived from the superoxide anion. Indeed, macrophages are essential for controlling most infections, and are 
mediators of inflammation.

Prostaglandin $\mathrm{D}_{2}\left(\mathrm{PGD}_{2}\right)$ is generated from arachidonic acid in a number of tissues by the sequential actions of prostaglandin $\mathrm{H}$ synthase and prostaglandin $\mathrm{D}$ synthase. $\mathrm{PGD}_{2}$ has been implicated in both central and peripheral physiological events. Peripherally, a large number of reports have focused on allergic disorders, platelet aggregation, vasodilation, pulmonary constriction, and bronchoconstriction ${ }^{1,2)}$. $\mathrm{PGD}_{2}$ is also a precursor of 15 -Deoxy- $\Delta^{12,14}$-prostaglandin $\mathrm{J}_{2}\left(\mathrm{dPGJ}_{2}\right) . \mathrm{dPGJ}_{2}$ is a natural ligand for the peroxisome proliferator-activated receptor $\gamma$ $(\operatorname{PPAR} \gamma)$, a nuclear receptor implicated in adipocyte differentiation and glucose homeostasis ${ }^{3-5}$. Recent studies documented the role of $\mathrm{dPGJ}_{2}$, a potent PPAR $\gamma$ ligand, as an anti-inflammatory agent ${ }^{6,7)}$. In fact, we have previously demonstrated that $\mathrm{dPGJ}_{2}$ markedly inhibits several kind of functions in macrophages $^{8,9}$. However, little attention has been paid to the effect of $\mathrm{PGD}_{2}$ on macrophage functions, although a recent study showed the possibility that $\mathrm{PGD}_{2}$ in addition to $\mathrm{dPGJ}_{2}$ may have anti-inflammatory properties $^{10)}$. These previous findings prompted us to examine the possible effects of $\mathrm{PGD}_{2}$ on inflammatory responses. For this purpose, in this study, we simultaneously examined the effect of BW245C, an agonist of prostanoid DP receptor, on chemotaxis, phagocytosis, superoxide anion production, nitric oxide production and TNF- $\alpha$ production by macrophages.

\section{Materials and Methods}

\section{Materials}

BW245C was obtained from Cayman Chemical (Ann Arbor, MI). Fluorescein-conjugated Escherichia coli bioparticles was purchased from Molecular Probes (Eugene, OA).

\section{Isolation of macrophages from peritoneum}

The protocol employed here meets the guidelines of the Japanese Society for Pharmacology. All efforts were made to minimize animal suffering and to reduce the number of animals used. Macrophages were isolated by peritoneal lavage from adult male Wistar rats weighing $200-250 \mathrm{~g}, 4$ days after the injection of
$20 \mathrm{~m} l$ of $1 \%$ glycogen. Lavage was performed by washing the peritoneal cavity with PBS supplemented with $20 \mathrm{U} / \mathrm{m} l$ heparin and $1 \mathrm{mM}$ EDTA. Care was taken not to cause internal bleeding while collecting macrophages in the exudate ${ }^{11}$. For the chemotaxis assay, the macrophages were allowed to adhere to plastic dishes for $2 \mathrm{~h}$. They were then resuspended in DMEM. For the other assays, macrophages in DMEM were used. The purity of the adherent cells exceeded $95 \%$ as determined by immunostaining with an antiED2 antibody (a macrophage marker).

\section{Chemotaxis assay}

The chemotaxis assay was performed as previously described $^{12)}$ with minor modifications ${ }^{13}$. In brief, zymosan-activated serum, prepared by a method reported elsewhere ${ }^{14)}$, was diluted to $5 \%$ in medium and placed in the lower compartment of 96-well microchemotaxis chambers as the stimulant. A polycarbonate filter with $5-\mu \mathrm{m}$ pores was placed on the wells. Experiments were initiated by adding the mixture containing macrophages ( $100 \mu l, 2 \times 10^{5}$ per well) with BW245C to the upper compartment of the chamber. After $90 \mathrm{~min}$, the cells on the filter were fixed with methanol and stained with Diff-Quick. The upper side of the filter was then scraped free of cells. The number of cells that migrated to the lower side was determined by measuring optical densities at $595 \mathrm{~nm}$.

\section{Phagocytosis assay}

The phagocytosis assay was performed as previously described ${ }^{15)}$ with minor modifications ${ }^{16}$. In brief, macrophages $\left(1 \times 10^{5}\right.$ per well) were allowed to adhere for $2 \mathrm{~h}$ and were then incubated with BW245C and fluorescein-conjugated $E$. coli $(\mathrm{K}-12)$ bioparticles at $1 \times 10^{6}$ per well. After incubation for $1 \mathrm{~h}$, extracellular fluorescence was quenched by adding $25 \mu \mathrm{g}$ trypan blue in $13 \mathrm{mM}$ citrate buffer ( $\mathrm{pH} 4.4$ ). The dye was removed after $1 \mathrm{~min}$ and the fluorescence intensity was determined.

\section{Superoxide anion production assay}

Superoxide anion production was detected by a method previously described ${ }^{17)}$ with minor modifications ${ }^{18)}$. In brief, macrophages $\left(1 \times 10^{5}\right.$ per well) were 
allowed to adhere for $2 \mathrm{~h}$ and were then incubated with BW245C containing PMA at $200 \mathrm{nM}$ and ferricytochrome $\mathrm{c}$ at $160 \mu \mathrm{M}$. Superoxide anion production was assessed by the inhibition of ferricytochrome c reduction using $600 \mathrm{U} / \mathrm{m} l$ superoxide dismutase. The absorbance at a wavelength of $550 \mathrm{~nm}$ was measured at different times after incubation.

\section{Nitrite production assay}

The concentrations of nitrite in the culture supernatants were determined by a microplate assay. In brief, macrophages $\left(1 \times 10^{5}\right.$ per well $)$ were allowed to adhere for $2 \mathrm{~h}$ and were then incubated with BW245C and LPS at $10 \mu \mathrm{g} / \mathrm{m} l$ for different times. After the supernatant was collected from the wells, the nitrite concentration was measured by commercially available Griess Reagent System (1\% sulfanilamide, 0.1\% naphthylethylenediamine dihydrochloride, $2.5 \%$ phosphoric acid, Promega ; Madison, WI) for $10 \mathrm{~min}$. The absorbance at a wavelength of $550 \mathrm{~nm}$ was measured. Nitrite concentrations were determined by using sodium nitrite as a standard.

\section{ELISA assay}

The TNF- $\alpha$ production assay was performed as previously described ${ }^{8)}$ with minor modifications ${ }^{19}$. In brief, macrophages $\left(1 \times 10^{6}\right.$ per well $)$ were allowed to adhere to 24-well plates for $2 \mathrm{~h}$ and were then incubated with BW245C and LPS at $2 \mathrm{ng} / \mathrm{m} l$ for $20 \mathrm{~h}$. After the supernatant was collected from the wells, the concentration of rat TNF- $\alpha$ was measured by commercially available ELISA (BioSource International, Camarillo, CA).

\section{Data analyses}

The results were all expressed as the mean $\pm \mathrm{S}$. E. and the statistical significance was determined by the unpaired-t-test followed by estimation of the least significant difference.

\section{Results}

\section{BW 245C inhibits chemotaxis toward zymosan-activated serum}

When the macrophages and BW245C were placed in

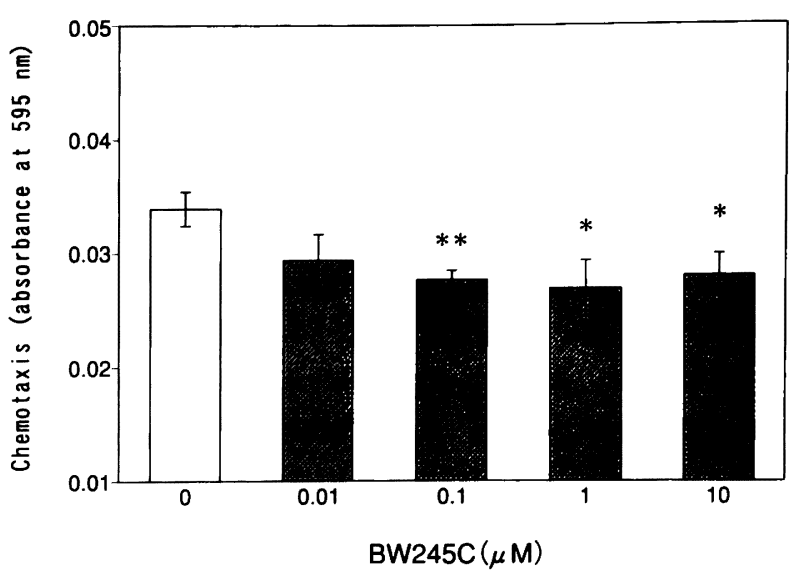

Fig. 1 BW245C inhibits macrophage chemotaxis towards zymosan-activated serum. Macrophages and BW245C were placed in the upper well, with zymosan-activated serum in the lower well, followed by incubation for $90 \mathrm{~min}$. The data from four individual animals are shown. ${ }^{*} \mathrm{p}<0.05 ;{ }^{* *} \mathrm{p}<$ 0.01 , when compared with untreated macrophages.

the upper well, with zymosan-activated serum in the lower well as a stimulant, BW245C markedly inhibited macrophage chemotaxis at a concentration range of 0.1 to $10 \mu \mathrm{M}$ (Fig. 1).

\section{BW245C inhibits phagocytosis of $E$. coli}

When determined under the conditions of the simultaneous addition of BW245C and E. coli, the addition of $10 \mu \mathrm{M}$ of BW245C inhibited the phagocytosis of $E$. coli by macrophages, with concentrations below $1 \mu \mathrm{M}$ being unchanged (Fig. 2, left panel). In contrast, pretreatment of macrophages with $\mathrm{BW} 245 \mathrm{C}$ at a concentration range of 0.01 to $10 \mu \mathrm{M}$ did not alter the phagocytosis of $E$. coli. However, pretreatment with BW245C at $50 \mu \mathrm{M}$ significantly suppressed phagocytosis (Fig. 2, right panel).

\section{BW245C inhibits superoxide anion production}

The addition of increasing concentrations of BW245C markedly blocked the production of superoxide anion by macrophages stimulated with PMA at $1 \mathrm{~h}$ after incubation (Fig. 3). This inhibition of superoxide anion production by BW245C persisted for at least $4 \mathrm{~h}$. However, the lowest concentration of BW245C did not affect the production. 


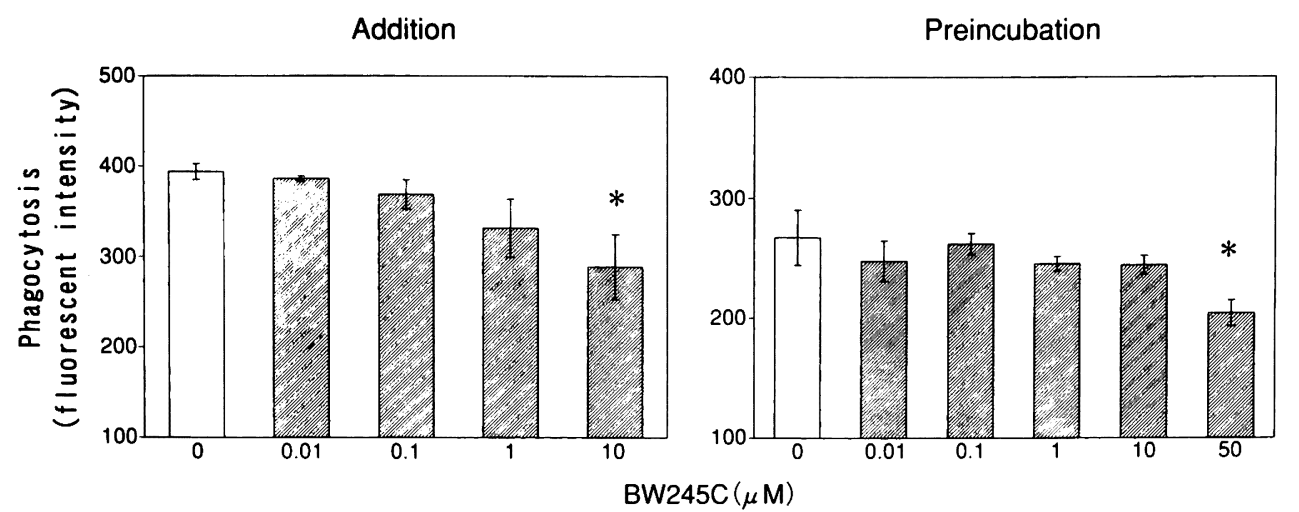

Fig. 2 BW245C inhibits the phagocytosis of $E$. coli by macrophages. Macrophages were allowed to adhere to plates for $2 \mathrm{~h}$. Adherent macrophages were incubated with BW245C and $E$. coli for $1 \mathrm{~h}$ (left panel). Adherent macrophages were preincubated with BW245C for $1 \mathrm{~h}$, followed by incubation with $E$. coli for $1 \mathrm{~h}$ (right panel). The data from three individual animals are shown. ${ }^{*} \mathrm{p}<0.05$, when compared with untreated macrophages.

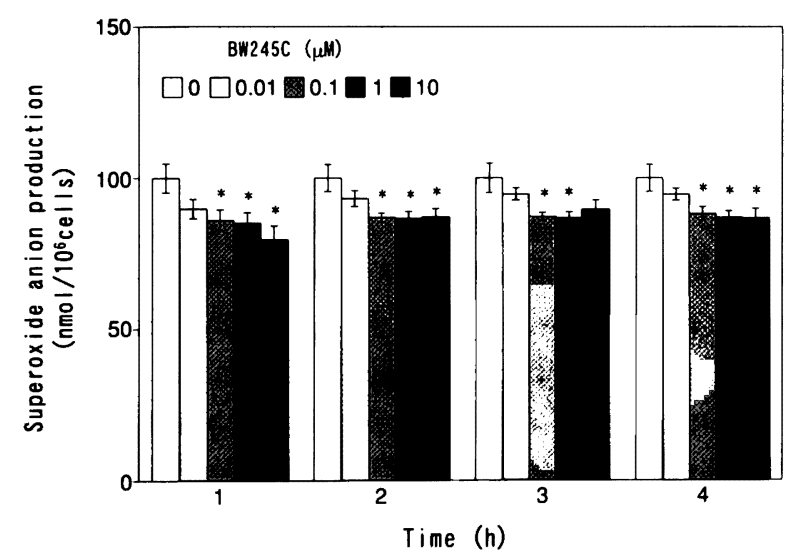

Fig. 3 BW245C inhibits the production of superoxide anion by macrophages. Macrophages were allowed to adhere to plates for $2 \mathrm{~h}$. Adherent macrophages were incubated with BW245C containing PMA at $200 \mathrm{nM}$ and ferricytochrome $\mathrm{c}$ at $160 \mu \mathrm{M}$. The data from six individual animals are shown. ${ }^{*} \mathrm{p}<0.05$, when compared with macrophages treated with PMA alone.

\section{BW245C inhibits nitrite production}

The addition of $\mathrm{BW} 245 \mathrm{C}$ at $10 \mu \mathrm{M}$ significantly inhibited nitrite production by macrophages stimulated with LPS at $3.5 \mathrm{~h}$ after incubation, with concentrations below $1 \mu \mathrm{M}$ being unchanged (Table 1 ). After incubation for $24 \mathrm{~h}$, however, BW245C did not affect the nitrite production at concentrations of up to $10 \mu \mathrm{M}$. When macrophages were pretreated with BW245C for $24 \mathrm{~h}$, followed by incubation with LPS for $24 \mathrm{~h}$, furthermore, BW245C was not found to affect the production (Table 1, right column).

\section{BW245C potentiates TNF- $\alpha$ production}

The addition of increasing concentrations of BW245C in the presence of LPS markedly potentiated the production of TNF- $\alpha$ as compared with macrophages in the absence of LPS (Fig. 4). In addition, BW245C at concentrations above $1 \mu \mathrm{M}$ significantly potentiated the LPS-stimulated TNF- $\alpha$ production. However, BW245C at $10 \mu \mathrm{M}$ induced less potent potentiation than at $1 \mu \mathrm{M}$. In contrast, BW245C at concentrations of up to $10 \mu \mathrm{M}$ alone did not alter the production of TNF- $\alpha$ by macrophages in the absence of LPS (data not shown).

\section{Discussion}

Chemotaxis plays an important role in the development of inflammatory diseases ${ }^{20,21}$. It requires the degradation of basal laminae and interstitial stroma, and the processes of chemotaxis involve matrix metalloproteinases, a family of endopeptidases capable of degrading extracellular matrix compo- 
Table 1 BW245C inhibits the production of nitrite by macrophages

\begin{tabular}{lccc}
\hline & \multicolumn{3}{c}{ Nitrite production $(\mu \mathrm{M})$} \\
\cline { 2 - 4 } & $3.5 \mathrm{~h}$ & $24 \mathrm{~h}$ & $24 \mathrm{~h}+24 \mathrm{~h}$ \\
\hline BW245C $(\mu \mathrm{M})$ & & & \\
0 & $7.59 \pm 1.8$ & $37.3 \pm 0.04$ & $17.6 \pm 0.29$ \\
0.01 & $7.37 \pm 0.6$ & $36.1 \pm 0.26$ & $17.0 \pm 0.74$ \\
0.1 & $7.54 \pm 0.6$ & $36.1 \pm 0.11$ & $18.3 \pm 0.26$ \\
1 & $7.30 \pm 1.0$ & $36.2 \pm 0.12$ & $18.1 \pm 0.31$ \\
10 & $6.87 \pm 0.7^{* *}$ & $36.4 \pm 0.18$ & $17.8 \pm 0.63$ \\
\hline
\end{tabular}

Macrophages were allowed to adhere to plates for $2 \mathrm{~h}$. Adherent macrophages were incubated with BW245C containing LPS at $10 \mu \mathrm{g} / \mathrm{m} l$ for 3.5 or $24 \mathrm{~h}$ (left and middle column). Adherent macrophages were preincubated with BW245C for $24 \mathrm{~h}$, followed by incubation with LPS at $10 \mu \mathrm{g} / \mathrm{m} l$ for $24 \mathrm{~h}$ (right column). The data from 3 to 5 individual animals are shown. ${ }^{* *} \mathrm{p}<$ 0.01 , when compared with macrophages treated with LPS alone.

nents ${ }^{22-24)}$. Several studies have reported that phosphoinositide 3 -kinase is associated with chemotaxis ${ }^{25}$, chemoattractant receptors that can activate at least both class $1 \mathrm{~A}$ and class $1 \mathrm{~B}$ phosphoinositide 3kinase. In addition, recent studies in transgenic mice found that the chemoattractant-induced formation of 3 '-phosphorylated lipids, the activation of protein kinase B (Akt), and chemotaxis depended entirely on p $110 \gamma$, the only known phosphoinositide 3-kinase of class $1 \mathrm{~B}^{25}$. However, there are no reports that $\mathrm{PGD}_{2}$ and/or DP receptor agonist can modulate matrix metalloproteinases or phosphoinositide 3-kinase in any cell types. The exact molecular mechanisms underlying the suppression of chemotaxis by BW245C, therefore, still remain to be elucidated in future studies.

In this study, BW245C at $10 \mu \mathrm{M}$ inhibited phagocytosis under the conditions employed in the simultaneous addition of BW245C and E. coli, but not under the conditions employed in preincubation with BW245C, followed by the addition of $E$. coli. Moreover, BW245C at $50 \mu \mathrm{M}$ inhibited phagocytosis under the conditions employed in preincubation. These data argue in favor of the idea that BW245C may act transiently, and the action time of BW245C may be

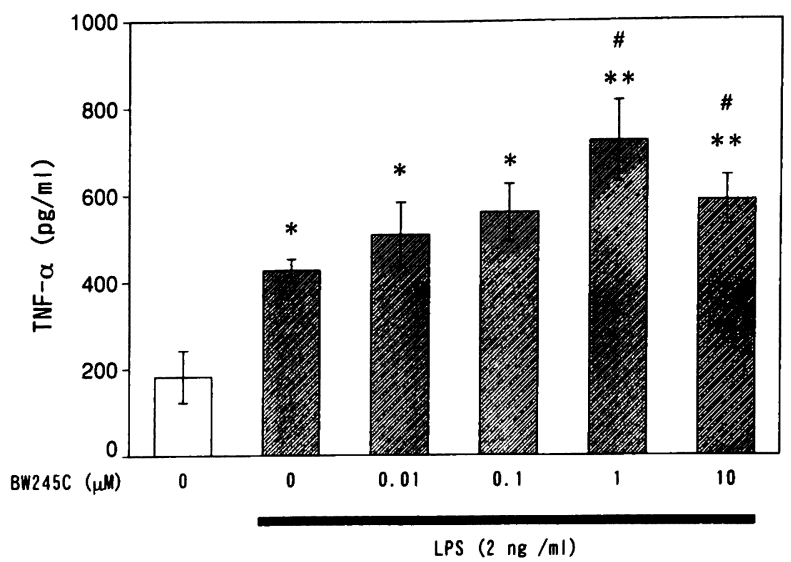

Fig. 4 BW245C potentiates the production of TNF- $\alpha$ by macrophages in response to LPS. Macrophages were allowed to adhere to plates for $2 \mathrm{~h}$. Adherent macrophages were incubated with BW245C and LPS at $2 \mathrm{ng} / \mathrm{m} l$ for $20 \mathrm{~h}$. The data from three individual animals are shown. ${ }^{*} \mathrm{p}<0.05 ;{ }^{* *} \mathrm{p}<$ 0.01 , when compared with untreated macrophages. ${ }^{\#} \mathrm{p}<0.05$, when compared with macrophages treated with LPS alone.

short.

This study shows that BW245C inhibits superoxide anion production by PMA-stimulated macrophages. PMA activates macrophages via the activation of protein kinase $\mathrm{C}$ and the subsequent phosphorylation of the cytosolic factor $\mathrm{p} 47^{\text {phox }}$ to produce superoxide anions $^{26-30}$. On the other hand, the DP receptor is coupled positively to adenyl cyclase through $\mathrm{G}_{\mathrm{s}}$, resulting in an increase in the intracellular concentration of cAMP. Recent findings have indicated that dibutyryl-cAMP, 8-bromo-cAMP (cell permeable cAMP analogs), forskolin (an adenyl-cyclase activator), and Ro 20-1724 (a phosphodiesterase inhibitor), but not 8-bromo-cGMP (cell permeable cGMP analogs) can inhibit superoxide anion production by PMA-stimulated macrophages ${ }^{31)}$. In addition, a previous study showed that cAMP down-regulates $\mathrm{PKC}_{\text {activation }}{ }^{32}$. These previous findings all support the present proposal that BW245C may inhibit superoxide anion production via the down-regulation of $\mathrm{PKC}$ by increased cAMP.

BW245C resulted in the less potent inhibition of nitrite production than that of superoxide anion 
production. The inhibition of nitrite production by BW245C did not appear in the conditions employed in both the long incubation time and preincubation. We used LPS as a stimulant in the nitrite production assay, because LPS can produce nitric oxide, followed by nitrite via the up-regulation of inducible nitric oxide synthase (iNOS). In the superoxide anion production assay, we used PMA as a stimulant. Our observations suggest that the DP receptor signal may selectively interact with the PKC pathway by PMA rather than the LPS signal pathway.

An interesting finding of this study is that BW245C potentiates the production of TNF- $\alpha$ by LPSstimulated macrophages. A previous study clearly demonstrated that pentoxifylline, which increases intracellular cAMP by inhibiting phosphodiesterase, inhibits the production of TNF- $\alpha$ by monocytes treated with both PMA and phytohemagglutinin ${ }^{33-36)}$. Another study showed that elevated cAMP inhibits the LPS-stimulated pathway in monocytes ${ }^{37}$. Again, the DP receptor potentiates adenyl cyclase. Therefore, it is unlikely that increased cAMP through the activation of DP receptor is associated with the further-potentiation of TNF- $\alpha$ production by LPSstimulated macrophages. There have been several reports that the TNF- $\alpha$ gene acts constitutively in macrophages and the regulation of TNF- $\alpha$ expression in LPS-stimulated macrophages occurs posttranscriptionally ${ }^{38,39)}$. Therefore, the possibility that activation of the DP receptor by BW245C may affect the transcription and/or post-transcription modulation of TNF- $\alpha$ mRNA cannot be ruled out.

On the other hand, $\mathrm{PGD}_{2}$ and $\mathrm{dPGJ}_{2}$ levels were increased in carrageenin-induced pleurisy in rats concomitant with the resolution of inflammation ${ }^{40)}$. In this model, the application of $\mathrm{PGD}_{2}$ and $\mathrm{dPGJ}_{2}$ can aid the resolution of inflammation ${ }^{40}$. This previous study suggested the possibility that $\mathrm{PGD}_{2}$ and $\mathrm{dPGJ}_{2}$ may have anti-inflammatory properties. It is not clear how $\mathrm{PGD}_{2}$ can aid the resolution of inflammation, however, although it was found that $\mathrm{dPGJ}_{2}$ acts as an anti-inflammatory via $\operatorname{PPAR} \gamma$. Furthermore, $\mathrm{PGD}_{2}$ synthase, which is required for $\mathrm{dPGJ}_{2}$ synthesis, is predominantly expressed in macrophages ${ }^{41}$. The question of whether $\mathrm{PGD}_{2}$ actively acts as an anti- inflammatory following enzymatic conversion into $\mathrm{dPGJ}_{2}$, or $\mathrm{PGD}_{2}$ directly acts as an anti-inflammatory via activation of DP receptor remains to be addressed before drawing any conclusions. It thus appears that BW245C clearly inhibited chemotaxis, phagocytosis, superoxide anion production and nitrite production, and potentiated TNF- $\alpha$ production by macrophages. The action mechanism of potentiation of BW245C on $\mathrm{TNF}-\alpha$ production by macrophages is currently under investigation.

\section{Acknowledgments}

This work was supported in part by a Grant-in-Aid for Scientific Research (C) (13671957) from the Japan Society for the Promotion of Science of Japan.

\section{References}

1) Negishi, M., Sugimoto, Y. and Ichikawa, A. : Prostanoid receptors and their biological actions. Prog. Lipid Res. 32 : 417-434, 1993.

2) Ito, S., Narumiya, S. and Hayaishi, O. : Prostaglandin $\mathrm{D}_{2}$ : a biochemical perspective. Prostaglandins Leukot. Essent. Fatty Acid 37 : 219-234, 1989.

3) Forman, B. M., Tontonoz, P., Chen, J., Brun, R. P., Spiegelman, B. M. and Evans, R. M. : 15-Deoxy$\Delta^{12,14}$-prostaglandin $\mathrm{J}_{2}$ is a ligand for the adipocyte determination factor PPAR $\gamma$. Cell $83: 803-812$, 1995.

4) Kliewer, S. A., Lenhard, J. M., Willson, T. M., Patel, I., Morris, D. C. and Lehmann, J. M. : A prostaglan$\operatorname{din} \mathrm{J}_{2}$ metabolite binds peroxisome proliferatoractivated receptor $\gamma$ and promotes adipocyte differentiation. Cell 83: 813-819, 1995.

5) Kliewer, S. A., Sundseth, S. S., Jones, S. A., Browns, P. J., Wisely, G. B., Koble, C. S., Denchand, P., Wahli, W., Willson, T. M., Lenhard, J. M. and Lehmann, J. M. : Fatty acids and eicosanoids regulate gene expression through direct interactions with peroxisome proliferator-activated receptor $\alpha$ and $\gamma$. Proc. Natl. Acad. Sci. U. S. A. $94:$ 4318-4323, 1997.

6) Greene, M. E., Blumberg, B., McBride, O. W., Yi, H. F., Kronquist, K., Kwan, K., Hsieh, L., Greene, G. and Nimer, S. D. : Isolation of the human perox isome proliferator activated receptor $\gamma$ cDNA: expression in hematopoietic cells and chromosomal mapping. Gene Expression 4 : 281-299, 1995. 
7) Ricote, M., Li, A. C., Willson, T. M., Kelly, C. J. and Glass, C. K. : The peroxisome proliferator-activated receptor- $\gamma$ is a negative regulator of macrophage activation. Nature $391: 79-82,1998$.

8) Azuma, Y., Shinohara, M., Wang, P. L. and Ohura, K. : 15-Deoxy- $\Delta^{12,14}$-prostaglandin $\mathrm{J}_{2}$ inhibits IL-10 and IL-12 production by macrophages. Biochem. Biophys. Res. Commun. 283 : 344-346, 2001.

9) Azuma, Y., Shinohara, M., Wang, P. L. and Ohura, $\mathrm{K}$. : 15 -Deoxy- $\Delta^{12,14}$-prostaglandin $\mathrm{J}_{2}$ is a negative regulator of macrophage functions. Int. Immunopharmacol. $1: 2101-2108,2001$.

10) Gilroy, D. W., Colville-Nash, P. R., Willis, D., Chivers, J., Paul-Clark, M. J. and Willoughby, D. A.: Inducible cyclooxygenase may have antiinflammatory properties. Nat. Med. 5:698-701, 1999.

11) Azuma, Y., Shinohara, M., Wang, P. L. and Ohura, K. : Quinolones alter defense reactions mediated by macrophages. Int. Immunopharmacol. 1 : 179-187, 2001.

12) Azuma, Y., Ohura, K., Wang, P. L. and Shinohara, M. : Endomorphins 1 and 2 modulate chemotaxis, phagocytosis and superoxide anion production by microglia. J. Neuroimmunol. 119 : 51-56, 2001.

13) Azuma, Y., Ohura, K., Wang, P. L. and Shinohara, M. : Endomorphins delay constitutive apoptosis and alter the innate host defense functions of neutrophils. Immunol. Lett. $81: 31-40,2002$.

14) Azuma, Y. and Ohura, K. : Comparison of the effect of lidocaine-epinephrine and prilocaine-felypressine to alter macrophage functions. Int. Immunopharmacol. $1: 911-923,2001$.

15) Wan, C. P., Park, C. S. and Lau, B. H. S. : A rapid and simple microfluorometric phagocytosis assay. J. Immunol. Methods 162: 1-7, 1993.

16) Azuma, Y., Shinohara, M., Wang, P. L. and Ohura, $\mathrm{K}$. : Differentiation by in vitro treatment of lidocaine-epinephrine and prilocaine-felypressine in neutrophils. Immunol. Lett. $77: 151-158,2001$.

17) Pick, E. and Mizel, D. : Rapid microassays for the measurement of superoxide and hydrogen peroxide production by macrophages in culture using an automatic enzyme immunoassay reader. J. Immunol. Methods 46:211-226, 1981.

18) Azuma, Y., Wang, P. L., Shinohara, M. and Ohura, $\mathrm{K}$.: Immunomodulation of the neutrophil respiratory burst by endomorphins 1 and 2. Immunol. Lett. 75: 55-59, 2000.
19) Azuma, Y., Shinohara, M., Wang, P. L., Hidaka, A. and Ohura, K.: Histamine inhibits chemotaxis, phagocytosis and superoxide anion production, and the production of TNF $\alpha$ and IL-12 by macrophages via $\mathrm{H}_{2}$-receptors. Int. Immunopharmacol. $\mathbf{1}$ : 1867-1875, 2001.

20) Ross, R. : Atherosclerosis-an inflammatory disease. N. Engl. J. Med. 340 : 115-126, 1999.

21) Simmons, K. M., Brown, K. A., Kirk, A. P., Perry, J. D. and Dumonde, D. C. : Enhanced chemotaxis of monocytes in rheumatoid arthritis. $\mathrm{Br}$. J. Rheumatol. $26: 245-250,1987$.

22) Watanabe, H., Nakanishi, I., Yamashita, K., Hayakawa, T. and Okada, Y.: Matrix metalloproteinase-9 (92 kDa gelatinase/type IV collagenase) from U 937 monoblastoid cells : correlation with cellular invasion. J. Cell. Sci. 104 : 991-999, 1993.

23) Campbell, E. J., Cury, J. D., Shapiro, S. D., Goldberg, G. I. and Welgus, H. G. : Neutral proteinases of human mononuclear phagocytes. Cellular differentiation markedly alters cell phenotype for serine proteinases, metalloproteinases, and tissue inhibitor of metalloproteinases. J. Immunol. 146:1286-1293, 1991.

24) Welgus, H. G., Campbell, E. J., Cury, J. D., Eisen, A. Z., Senior, R. M., Wilhelm, S. M. and Goldberg, G. I. : Neutral metalloproteinases produced by human mononuclear phagocytes. Enzyme profile, regulation, and expression during cellular development. J. Clin. Invest. $86: 1496-1502,1990$.

25) Servant, G., Weiner, O. D., Herzmark, P., Balla, T., Sedat, J. W. and Boume, H. R. : Polarization of chemoattractant receptor signaling during neutrophil chemotaxis. Science 287 : 1037-1040, 2000.

26) Gerard, C., McPhail, L. C., Marfat, A., StimlerGerard, N. P., Bass, D. A. and McCall, C. E. : Role of protein kinases in stimulation of human polymorphonuclear leukocyte oxidative metabolism by various agonists. J. Clin. Invest. $77: 61-65,1986$.

27) Tauber, A. I. : Protein kinase $C$ and the activation of the human neutrophil NADPH-oxidase. Blood 69:711-720, 1987.

28) Kessels, G. C. R., Krause, K. and Verhoeven, A. J. : Protein kinase $\mathrm{C}$ activity is not involved in $\mathrm{N}$-formylmethionyl-leucyl-phenylalanine-induced phospholipase $\mathrm{D}$ activation in human neutrophils, but is essential for concomitant NADPH oxidase activation: Studies with a staurosporine analogue with improved selectivity for protein kinase C. Biochem. 
J. $292: 781-785,1993$.

29) Tardif, M., Rabiet, M. J., Christophe, T., Milcent, M. D. and Boulay, F. : Isolation and characterization of a variant HL 60 cell line defective in the activation of the NADPH oxidase by phorbol myristate acetate. J. Immunol. 161: 6885-6895, 1998.

30) Nauseef, W. M. : Cytosolic oxidase factors in the NADPH-dependent oxidase of human neutrophils. Eur. J. Haematol. 51 : 301-308, 1993.

31) Si, Q. S., Nakamura, Y. and Kataoka, K. : Adenosine inhibits superoxide production in rat peritoneal macrophages via elevation of cAMP level. Immunopharmacology $\mathbf{3 6}:$ 1-7, 1997.

32) Nishizuka, Y. : Studies and prospective of protein kinase C. Science $233:$ 305-312, 1986.

33) D'Hellencourt, C. L., Diaw, L., Cornillet, P. and Guenounou, M. : Differential regulation of $\mathrm{TNF} \alpha$, IL- $1 \beta$, IL-6, IL-8, TNF $\beta$ and IL-10 by pentoxifylline. Int. J. Immunopharmacol. 18: 739-748, 1996.

34) Strieter, R. M., Remic, D. G., Ward, P. A., Spengler, R. N., Lynch, J. P., Larrick, J. and Kunkel, S. L. : Cellular and molecular regulation of TNF-alpha production by pentoxifylline. Biochem. Biophys. Res. Commun. 155 : 1230-1236, 1988.

35) Endres, S., Fulle, H. J., Sinha, B., Stoll, D., Dinarello, C. A., Gerzer, R. and Weber, P.C.: Cyclic nucleotides differentially regulate the synthesis of tumor necrosis factor- $\alpha$ and interleukin- $1 \beta$ by human mononuclear cells. Immunology $72: 56-60$,
1991.

36) Schandené, L., Vandenbussche, P., Crusiaux, A., Alègre, M. L., Abramowicz, D., Dupont, E., Content, J. and Goldman, M. : Differential effects of pentoxifylline on the production of tumor necrosis factor$\alpha(\mathrm{TNF}-\alpha)$ and interleukin-6 (IL-6) by monocytes and $\mathrm{T}$ cells. Immunology $\mathbf{7 6}: 30-40,1992$.

37) Hurme, M. : Modulation of interleukin-1 $\beta$ production by cyclic AMP in human monocytes. FEBS Lett. $263:$ 35-37, 1990.

38) Beutler, B. : Application of transcriptional and posttranscriptional receptor constructs to the analysis of tumor necrosis factor gene regulation. Am. J. Med. Sci. 303 : 129-133, 1992.

39) Kruys, V., Kemmer, K., Shakhov, A., Jongeneel, V. and Beutler, B. : Constitutive activity of the tumor necrosis factor promoter is canceled by the 3 ' untranslated region in non macrophage cell lines ; a trans-dominant factor overcomes this suppressive effect. Proc. Natl. Acad. Sci. U. S. A. 89 : 673-677, 1992.

40) Gilroy, D. W., Colville-Nash, P. R., Chivers, J., Paul-Clark, M. J. and Willoughby, D. A. : Inducible cyclooxygenase may have anti-inflammatory properties. Nat. Med. 5:698-701, 1999.

41) Urade, Y., Ujihara, M., Horiguchi, Y., Ikai, K. and Hayaishi, O.: The major source of endogenous prostaglandin $\mathrm{D}_{2}$ production is likely antigenpresenting cells. J. Immunol. $143: 2982-2989,1989$. 